\title{
MOLECULAR EPIDEMIOLOGY OF A NOSOCOMIAL OUTBREAK DUE TO Enterobacter cloacae AND Enterobacter agglomerans IN CAMPINAS, SÃO PAULO, BRAZIL
}

\author{
Célia R. GONÇALVES(1), Tania M.I.VAZ(1), Daniela LEITE(1), Beatriz PISANI(2), Marise SIMÕES(2), Maria Angela M. PRANDI(2), Marilu M.M. ROCHA(2), \\ Paulo C. CESAR(3), Plinio TRABASSO(4), Angela von NOWAKONSKI(4) \& Kinue IRINO(1)
}

\begin{abstract}
SUMMARY
A total of 73 isolates (57 Enterobacter cloacae and 16 Enterobacter agglomerans), recovered during an outbreak of bacteremia in the Campinas area, São Paulo, Brazil, were studied. Of these isolates, 61 were from parenteral nutrition solutions, 9 from blood cultures, 2 from a sealed bottle of parenteral nutrition solution, and one was of unknown origin. Of the 57 E. cloacae isolates, 54 were biotype 26, two were biotype 66 and one was non-typable. Of 39 E. cloacae isolates submitted to ribotyping, $87.2 \%$ showed the same banding pattern after cleavage with EcoRI and BamHI. No important differences were observed in the antimicrobial susceptibility patterns among E. cloacae isolates exhibiting the same biotype, serotype and ribotype. All E. agglomerans isolates, irrespective of their origin, showed same patterns when cleaved with EcoRI and BamHI. The results of this investigation suggest an intrinsic contamination of parenteral nutrition solutions and incriminate these products as a vehicle of infection in this outbreak.
\end{abstract}

KEYWORDS: Nosocomial outbreak; Enterobacter cloacae; Enterobacter agglomerans; Serotypes; Ribotyping .

\section{INTRODUCTION}

Enterobacter species are emerging as important human pathogens, particularly among hospitalized patients ${ }^{5,14,33,37}$. Among 13 species currently recognized as members of the genus Enterobacter ${ }^{11,12}, E$. cloacae and E. aerogenes are the most frequently isolated species associated with human diseases ${ }^{1,10,17,19,30}$. E. agglomerans, commonly found in plants, soil, water and food stuffs, although rarely recognized as an agent of endogenous nosocomial infections ${ }^{6,8,14}$, can cause epidemics among hospitalized patients when associated with the use of contaminated intravenous products due to its ability to grow in commercial infusion fluids ${ }^{22,23}$.

Single source outbreaks of Enterobacter infections have been frequently traced to contaminated intravenous products, blood products, distilled water and pressure monitoring devices ${ }^{2,7,22,24,25,31,32,34,35}$. A longlasting epidemic caused by Enterobacter spp involving many hospitals and associated with the use of intrinsically contaminated intravenous solutions was reported in the 1970's in the United States by MAKI et al. ${ }^{22}$.

In March 24, 1997, one hospital of Campinas County, São Paulo State, Brazil, notified the Municipal Secretary of Health of an outbreak of bacteremia associated with intravenous therapy. According to the epidemiological investigation ${ }^{28}$, this outbreak began between 21 and 22 March, and was associated with the use of a parenteral nutrition solution produced by one manufacturer and bearing the same batch number.
Enterobacter cloacae and Enterobacter agglomerans were isolated from in-use infusion bags available in two of eight affected hospitals of Campinas County. Among 49 affected patients of this Municipality, 12 died (two adults and 10 newborns). Bacteremia was the typical clinical manifestation seen in the majority of patients receiving infusion bags after delivered by the manufacturer.

The purpose of this study was to investigate, by phenotypical and genotypic methods, the relatedness of E. cloacae and E. agglomerans strains recovered during this outbreak.

\section{MATERIAL AND METHODS}

Bacterial strains. A total of 73 isolates, 57 of them Enterobacter cloacae, and 16 Enterobacter agglomerans, were studied. Of the $57 \mathrm{E}$. cloacae isolates, 7 were from blood cultures, 48 from solutions administered to patients, one was from a sealed bottle and one was of unknown origin. Concerning the 16 E. agglomerans isolates, 2 were isolated from blood cultures, 13 from solutions administered to patients and one was from a sealed bottle. These isolates were recovered at Instituto Adolfo Lutz, Regional Laboratory, Campinas, in the Department of Clinical Microbiology of Campinas University, UNICAMP, and in the Laboratory of the Hospital "Maternidade de Campinas", Campinas, São Paulo, Brazil. All isolates were recovered in March 1997 during an outbreak of bacteremia that occurred in hospitals using parenteral nutrition solutions produced by one manufacturer.

(1) Instituto Adolfo Lutz, São Paulo, SP, Brasil.

(2) Instituto Adolfo Lutz, Campinas, SP, Brasil.

(3) Maternidade de Campinas, Campinas, SP, Brasil

(4) Universidade de Campinas, Campinas, SP, Brasil.

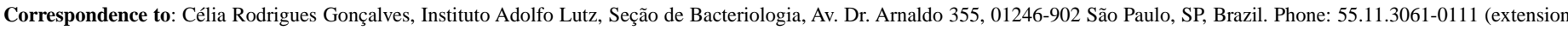
2058). FAX: 55.11.853-3505. 


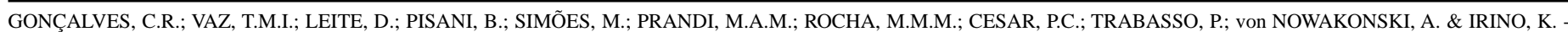
Molecular epidemiology of a nosocomial outbreak due to Enterobacter cloacae and Enterobacter agglomerans in Campinas, São Paulo, Brazil. Rev. Inst. Med. trop. S. Paulo, 42 (1): $1-7,2000$.

\section{Table 1}

Origin and phenotypic and genotypic characteristics of enterobacteria isolated during the outbreak associated with the use of parenteral nutrition solution, March, 1997.

\begin{tabular}{|c|c|c|c|c|c|c|}
\hline Patient & Source & Microorganism & Biotype & Serotype & Ribotype & Antimicrobial Resistance Pattern \\
\hline \multirow[t]{2}{*}{1} & \multirow[t]{2}{*}{$\mathrm{PNS}^{1}$} & E. cloacae & 26 & $\mathrm{O} 3$ & E1B1 & CX CF AP GN \\
\hline & & E. cloacae & 66 & $\mathrm{NT}^{2}$ & E3B3 & CX CF AP \\
\hline 2 & PNS & E. cloacae & NT & NT & E5B5 & CX CF AP \\
\hline 3 & PNS & E. cloacae & 26 & $\mathrm{O} 3$ & E1B1 & CX CF GN \\
\hline \multirow[t]{5}{*}{4} & \multirow[t]{3}{*}{ PNS } & E. cloacae & 26 & $\mathrm{O} 3$ & E1B1 & CX CF AP GN \\
\hline & & E. cloacae & 26 & $\mathrm{R}$ & E1B1 & CX CF GN \\
\hline & & E. agglomerans & -3 & - & E6B6 & $\mathrm{S}$ \\
\hline & \multirow[t]{2}{*}{ Blood } & E. cloacae & 26 & $\mathrm{O} 3$ & E1B1 & CX CF AP GN \\
\hline & & E. agglomerans & - & - & E6B6 & $\mathrm{S}^{4}$ \\
\hline \multirow[t]{4}{*}{5} & \multirow[t]{4}{*}{ PNS } & E. cloacae & 26 & $\mathrm{O} 3$ & E1B1 & CX CF AP GN \\
\hline & & E. cloacae & 26 & $\mathrm{R}^{5}$ & E1B1 & CX CF GN \\
\hline & & E. cloacae & 26 & $\mathrm{O} 3$ & - & CX CF AP GN \\
\hline & & E. agglomerans & - & - & E6B6 & $\mathrm{S}$ \\
\hline \multirow[t]{5}{*}{6} & \multirow[t]{4}{*}{ PNS } & E. cloacae & 26 & $\mathrm{O} 3$ & E1B1 & CX CF AP GN \\
\hline & & E. cloacae & 26 & $\mathrm{R}$ & E1B1 & CX CF AP GN \\
\hline & & E. cloacae & 26 & $\mathrm{O} 3$ & - & CX CF AP GN \\
\hline & & E. agglomerans & - & - & E6B6 & $S$ \\
\hline & Blood & E. cloacae & 26 & 03 & E1B1 & CX CF AP GN \\
\hline \multirow[t]{4}{*}{7} & \multirow[t]{4}{*}{ PNS } & E. cloacae & 26 & $\mathrm{O} 3$ & E1B1 & CX CL AP GN \\
\hline & & E. cloacae & 66 & NT & E4B4 & Multiresistant ${ }^{6}$ \\
\hline & & E. cloacae & 26 & $\mathrm{O} 3$ & - & CX CF AP GN \\
\hline & & E. agglomerans & - & - & E6B6 & Multiresistant $^{7}$ \\
\hline 8 & PNS & E. cloacae & 26 & O19 & $\mathrm{E} 2 \mathrm{~B} 2$ & Multiresistant $^{8}$ \\
\hline \multirow[t]{5}{*}{9} & \multirow[t]{4}{*}{ PNS } & E. cloacae & 26 & $\mathrm{O} 3$ & E1B1 & CX CF AP GN \\
\hline & & E. cloacae & 26 & $\mathrm{R}$ & - & CX CF AP GN \\
\hline & & E. cloacae & 26 & $\mathrm{R}$ & - & CX CF AP GN \\
\hline & & E. agglomerans & - & - & E6B6 & $\mathrm{S}$ \\
\hline & Blood & E. cloacae & 26 & $\mathrm{O} 3$ & E1B1 & CX CF AP GN \\
\hline \multirow[t]{3}{*}{10} & \multirow[t]{3}{*}{ PNS } & E. cloacae & 26 & $\mathrm{O} 3$ & E1B1 & CX CF AP GN \\
\hline & & E. cloacae & 26 & $\mathrm{O} 3$ & - & CX CF AP GN \\
\hline & & E. cloacae & 26 & $\mathrm{R}$ & - & CX CF AP GN \\
\hline 11 & Blood & E. cloacae & 26 & $\mathrm{R}$ & E1B1 & CX CF AP GN \\
\hline 12 & PNS & E. cloacae & 26 & $\mathrm{O} 3$ & E1B1 & CX CF AP GN \\
\hline
\end{tabular}




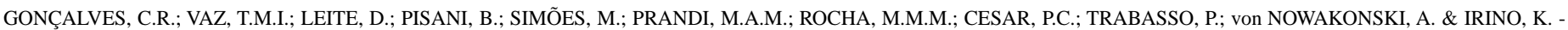

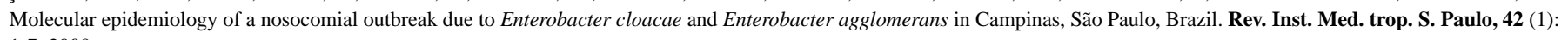
$1-7,2000$.

\begin{tabular}{|c|c|c|c|c|c|c|}
\hline Patient & Source & Microorganism & Biotype & Serotype & Ribotype & Antimicrobial Resistance Pattern \\
\hline \multirow[t]{4}{*}{13} & \multirow[t]{3}{*}{ PNS } & E. cloacae & 26 & $\mathrm{O} 3$ & E1B1 & CX CF AP GN \\
\hline & & E. cloacae & 26 & $\mathrm{O} 3$ & - & CX CF AP GN \\
\hline & & E. agglomerans & - & - & E6B6 & $\mathrm{S}$ \\
\hline & $?$ & E. cloacae & 26 & $\mathrm{O} 3$ & E1B1 & $\mathrm{CX}$ CF \\
\hline \multirow[t]{3}{*}{14} & \multirow{3}{*}{ PNS } & E. cloacae & 26 & $\mathrm{O} 3$ & E1B1 & CX CF AP GN \\
\hline & & E. cloacae & 26 & $\mathrm{R}$ & - & CX CF AP GN \\
\hline & & E. agglomerans & - & - & E6B6 & $\mathrm{S}$ \\
\hline \multirow[t]{3}{*}{15} & \multirow{3}{*}{ PNS } & E. cloacae & 26 & $\mathrm{O} 3$ & E1B1 & CX CF AP GN \\
\hline & & E. cloacae & 26 & $\mathrm{O} 3$ & - & CX CF AP GN \\
\hline & & E. cloacae & 26 & $\mathrm{R}$ & - & CX CF AP GN \\
\hline \multirow[t]{2}{*}{16} & \multirow[t]{2}{*}{ PNS } & E. cloacae & 26 & $\mathrm{O} 3$ & E1B1 & CX CF AP GN \\
\hline & & E. cloacae & 26 & $\mathrm{O} 3$ & - & CX CF AP GN \\
\hline 17 & PNS & E. cloacae & 26 & $\mathrm{O} 3$ & E1B1 & CX CF AP GN \\
\hline \multirow[t]{3}{*}{18} & \multirow[t]{2}{*}{ PNS } & E. cloacae & 26 & $\mathrm{O} 3$ & E1B1 & CX CF AP GN \\
\hline & & E. agglomerans & - & - & E6B6 & $\mathrm{S}$ \\
\hline & Blood & E. agglomerans & - & - & E6B6 & $S$ \\
\hline 19 & Blood & E. cloacae & 26 & $\mathrm{O} 3$ & E1B1 & CX CF AP GN \\
\hline \multirow[t]{3}{*}{20} & \multirow[t]{3}{*}{ PNS } & E. cloacae & 26 & $\mathrm{R}$ & E1B1 & CX CF AP GN \\
\hline & & E. cloacae & 26 & $\mathrm{R}$ & - & CX CF AP GN \\
\hline & & E. agglomerans & - & - & E6B6 & $\mathrm{S}$ \\
\hline \multirow[t]{7}{*}{21} & \multirow[t]{7}{*}{ PNS } & E. cloacae & 26 & $\mathrm{O} 3$ & E1B1 & CX CF AP GN \\
\hline & & E. cloacae & 26 & $\mathrm{O} 3$ & - & CX CF AP GN \\
\hline & & E. cloacae & 26 & $\mathrm{O} 3$ & - & CX CF AP GN \\
\hline & & E. cloacae & 26 & $\mathrm{R}$ & - & CX CF AP GN \\
\hline & & E. agglomerans & - & - & E6B6 & $\mathrm{S}$ \\
\hline & & E. agglomerans & - & - & E6B6 & AP GN TT \\
\hline & & E. agglomerans & - & - & - & $\mathrm{S}$ \\
\hline 22 & PNS & E. cloacae & 26 & $\mathrm{O} 3$ & E1B1 & CX CF AP GN \\
\hline 23 & PNS & E. cloacae & 26 & $\mathrm{O} 3$ & E1B1 & CX CF AP GN \\
\hline 24 & PNS & E. cloacae & 26 & $\mathrm{O} 14$ & NT & CX CF AP \\
\hline \multirow[t]{4}{*}{25} & \multirow[t]{4}{*}{ PNS } & E. cloacae & 26 & $\mathrm{O} 3$ & E1B1 & CX CF AP GN \\
\hline & & E. cloacae & 26 & $\mathrm{O} 3$ & - & CX CF AP GN \\
\hline & & E. cloacae & 26 & $\mathrm{R}$ & - & CX CF AP GN \\
\hline & & E. agglomerans & - & - & E6B6 & AP GN TT \\
\hline 26 & PNS & E. cloacae & 26 & $\mathrm{O} 3$ & E1B1 & CX CF AP GN \\
\hline 27 & PNS & E. cloacae & 26 & $\mathrm{O} 3$ & E1B1 & CX CF AP GN \\
\hline 28 & Blood & E. cloacae & 26 & $\mathrm{O} 3$ & E1B1 & CX CF AP GN \\
\hline \multirow[t]{3}{*}{29} & Blood & E. cloacae & 26 & $\mathrm{O} 3$ & $\mathrm{E} 1 \mathrm{~B} 1$ & CX CF AP GN \\
\hline & \multirow[t]{2}{*}{ Sealed Bottle } & E. cloacae & 26 & $\mathrm{O} 3$ & E1B1 & CX CF AP GN \\
\hline & & E. agglomerans & - & - & E6B6 & \\
\hline
\end{tabular}

$\mathrm{PNS}^{1}$ (parenteral nutrition solution); $\mathrm{NT}^{2}$ (non-typable); $-^{3}$ (not tested); $\mathrm{S}^{4}$ (susceptible to all tested drugs); $\mathrm{R}^{5}$ (rough strain); multiresistant ${ }^{6}$ (resistant to CX,CF, AP, AM, TT,CLO, SUT, CPZ, CRX); multiresistant ${ }^{7}$ (resistant to AP, TT,AM,GN,CLO); multiresistant ${ }^{8}$ (resistant to CX,CF,AP,TT,AM,SUT,CPZ,GN,CTX); ? (unknown origin) 


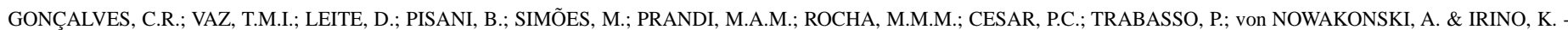
Molecular epidemiology of a nosocomial outbreak due to Enterobacter cloacae and Enterobacter agglomerans in Campinas, São Paulo, Brazil. Rev. Inst. Med. trop. S. Paulo, 42 (1): $1-7,2000$.

Biochemical identification. All isolates were subjected to biochemical identification ${ }^{9}$, and all E. cloacae were biotyped as previously described ${ }^{27,36}$.

Serotyping. Nineteen E. cloacae isolates were serotyped in the Central Public Health Laboratory, Laboratory of Hospital Infection, Colindale, London, UK. The remaining 38 E. cloacae were serotyped at Instituto Adolfo Lutz, Central Public Health Laboratory, using O-antisera prepared with standard E. cloacae strains received from the Laboratory of Hospital Infection, London, UK. O-serotyping was performed according to methods previously described ${ }^{15}$.

Antibiotic susceptibility testing. The susceptibility of all isolates to antimicrobial agents was determined by the standard disk diffusion method $^{26}$ using the following commercial disks (Cecon, Centro de Controle e Produtos para Diagnósticos, S. Paulo, Brazil): amikacin (AM,

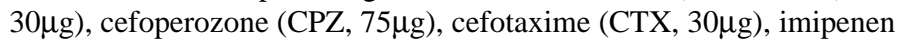
(IPM, $10 \mu \mathrm{g}$ ), ciprofloxacin (CIP, $5 \mu \mathrm{g}$ ), tetracyclin (TT, 30 $\mu \mathrm{g}$ ), chloramphenicol (CLO, 30 $\mu \mathrm{g}$ ), sulfamethoxazole-trimethoprim (SUT, $1.25 / 23.75 \mu \mathrm{g}$ ), ampicillin (AP, $10 \mu \mathrm{g}$ ), cephalotin (CF, 30 $\mu \mathrm{g}$ ), gentamicin $(\mathrm{GN}, 10 \mu \mathrm{g})$, and cephalexin $(\mathrm{CX}, 30 \mu \mathrm{g})$.

Ribotyping. All isolates recovered from blood cultures were ribotyped as well as the isolates from sealed bottle. Among isolates from in-use parenteral nutrition solutions we selected at least one isolate of each bottle. Chromosomal DNA of E. cloacae and E. agglomerans was extracted and purified as previously described ${ }^{3}$. DNA samples $(3 \mu \mathrm{g})$ were cleaved with the restriction enzymes EcoRI and BamHI according to the reaction conditions recommended by the manufacturer (Pharmacia, LKB). DNA fragments were subjected to horizontal electrophoresis in $0.8 \%$ agarose (Sigma) in 0.04 M TRIS-acetate and 0.001 M EDTA buffer, and restriction fragments were transferred under vacuum (Vacugene, Pharmacia, LKB) to nylon membranes. The membranes were hybridized with the $16+23 \mathrm{~S}$ cDNA probe transcribed by reverse transcriptase from E. coli rRNA (Boerhinger Mannheim, Germany) and labelled with digoxigenin according to POPOVIC et al. ${ }^{29}$. A Haemophilus aegyptius (strain \# 3031) EcoRI DNA digest (fragment sizes of 1492 ,1713, 3228, $3789,4960,5575,6334$, and 17613 bp) was used as molecular marker. Fragment sizes were estimated with a computer program (DNASTAR Computer System for Molecular Biology and Genetics, London, UK).

\section{RESULTS}

Biotyping and serotyping. Of $E$. cloacae isolates 39 were assigned to biotype 26 / serotype O3, 13 to biotype 26 / OR ( rough ), four belonged to other biotypes / serotypes and one was non-typable by biotyping or serotyping. The characteristics of all strains are summarized in Table 1.

Antimicrobial susceptibility patterns. The majority of E. cloacae showed no important differences in the antimicrobial susceptibility patterns, being homogeneously resistant to ampicillin, cephalothin, cephalexin, and gentamicin. One isolate of biotype 26 / O19 and one of biotype 66 / NT were resistant to 9 drugs. Of 16 E. agglomerans isolates, 13 were susceptible to all tested drugs, 2 were resistant to ampicillin, gentamicin and tetracycline and one was resistant to ampicillin, gentamicin, tetracycline, amikacin and chloramphenicol.
Ribotyping. DNA samples of 39 E. cloacae and 15 E. agglomerans were digested with EcoRI and BamHI. All 34 E. cloacae isolates belonging to biotype 26 and to serotype O3 or OR (rough isolates), irrespective of their origin (solution administered to patients, sealed bottle of parenteral nutrition solution and blood cultures) were homogeneously cleaved with Eco RI, generating 16 fragments ranging in size from 1.3 to $22.9 \mathrm{kp}$, and were assigned to pattern E1. These 34 isolates, which also showed a unique pattern (B1) with 8 bands ranging in size from 6.0 to $25.8 \mathrm{kp}$ when cleaved with $\mathrm{Bam} \mathrm{HI}$, were assigned to ribotype E1B1. DNA sample (extraction was repeated twice) of one E. cloacae isolate (biotype 26/ serotype O14) was sheared and was not digested. E. cloacae isolates belonging to biotype 26 / serotype O19 (one isolate), biotype 66 / NT (two isolates) and NT / NT (one isolate) displayed patterns distinct from E1B1 when cleaved with EcoRI or BamHI and were classified as ribotypes E2B2, E3B3, E4B4, and E5B5, respectively. All E. agglomerans isolates when cleaved with $E c o \mathrm{RI}$ showed a unique pattern (E6) with 12 fragments ranging from 1.7 to $14.5 \mathrm{kp}$. The homogeneity of these isolates was confirmed with the second enzyme BamHI. All E. agglomerans isolates were classified as ribotype E6B6. Figure 1 shows the banding patterns of E. cloacae and E. agglomerans recovered from solutions administered to patients, from blood cultures and from one sealed bottle of parenteral nutrition solution, after digestion with EcoRI and BamHI, respectively. Schematic representation of the banding patterns of ribotypes of E. cloacae and E. agglomerans is shown in Figure 2.

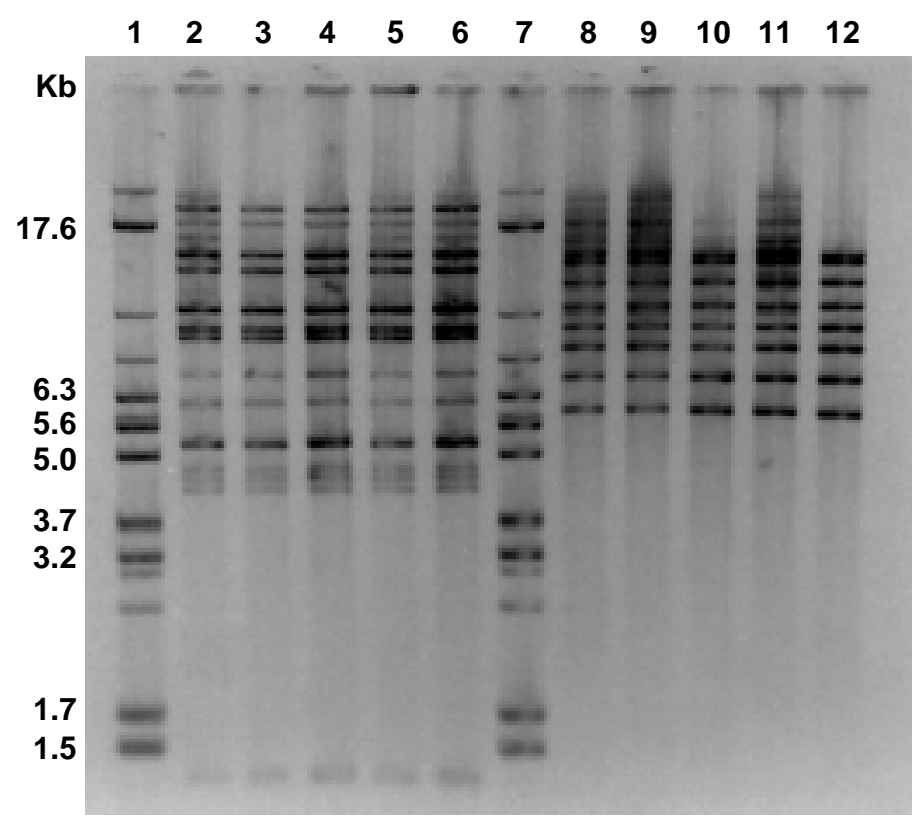

Fig. 1 - Banding patterns of E. cloacae belonging to biotype 26/serotype O3 (lanes 2 to 6) generated by EcoRI (pattern E1), and of E. agglomerans (lanes 8 to 12) after cleavage with Bam HI (pattern B6). Isolates were obtained from blood cultures (lanes 2, 3, 8, and 9), solutions administered to patients (lanes 4, 510 and 11) and sealed bottle (lanes 6 and 12). Lane 1 and 7, size marker (H. aegyptius 3031 EcoRI DNA digest, fragment size in kilobases). 


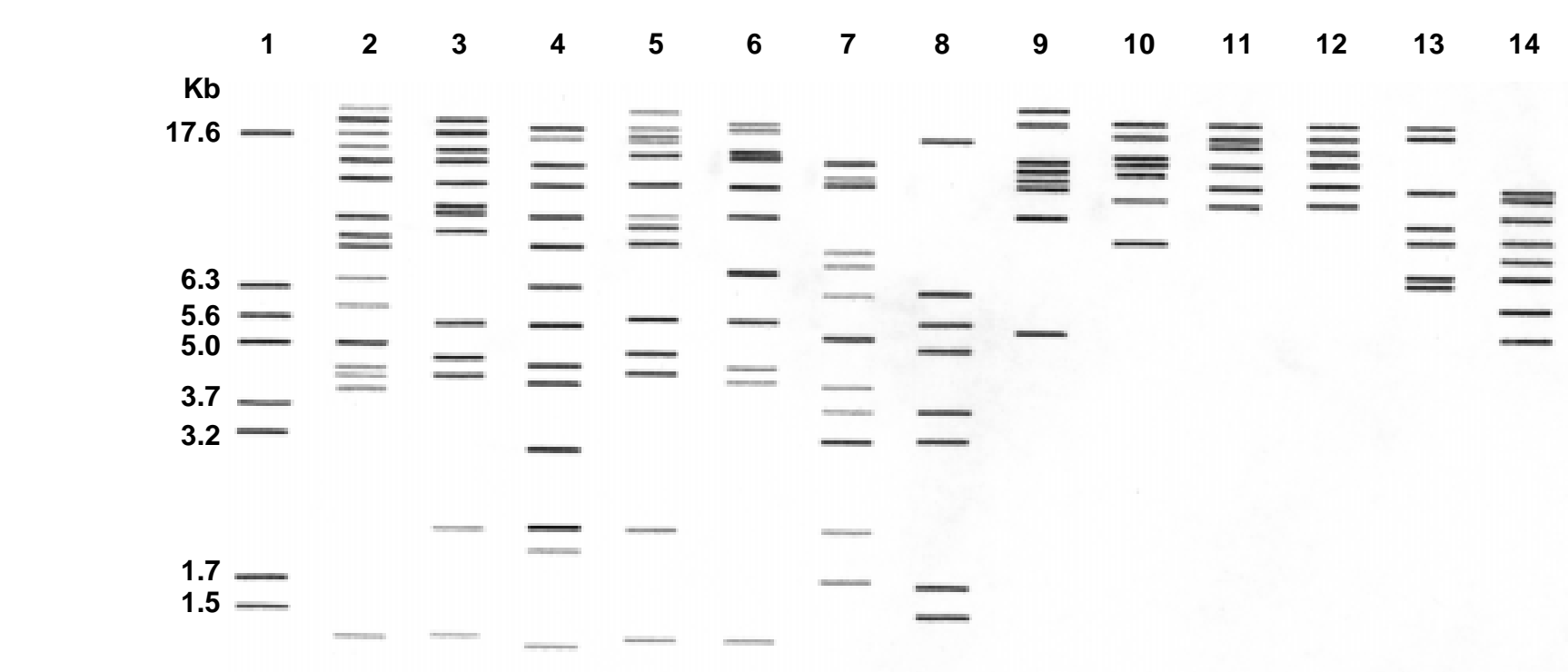

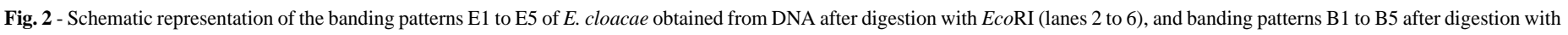

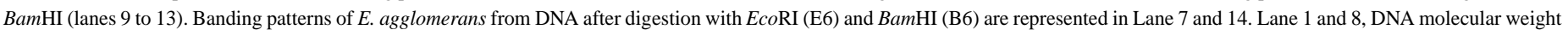
marker.

\section{DISCUSSION}

Phenotypic methods when used in combination could be sufficiently discriminatory and satisfactory to differentiate the majority of clinical isolates of $E$. cloacae $e^{13,36}$. Using conventional typing methods, we could differentiate a main group of 39 E. cloacae represented by isolates characterized as biotype 26 / serotype O3. E. cloacae serotype O3 strains are the most frequently isolated serotype from human infections ${ }^{16,36}$ and are probably widely disseminated in the environment.

This group of phenotypically similar isolates was genetically homogeneous as determined by ribotyping. On the other hand, four isolates which belonged to distinct biotypes and serotypes were also heterogeneous when assayed by ribotyping.

Biochemical and genotypic similarities shared by E. cloacae isolated from a sealed bottle of parenteral nutrition solution and E. cloacae isolated from solutions administered to patients point to the intrinsic contamination of these solutions, probably from environmental origin because of the antimicrobial susceptibilty pattern. Extrinsic contamination of the solutions administered to patients is unlikely, considering that nocomial strains of E. cloacae are usually multiresistant.

Multiple resistant E. cloacae strains belonging to some biotypes such as biotype 26 and 66 are frequently associated with human infections probably because these strains are present in some hospital units such as intensive care units ${ }^{37}$. It was not surprising that such nosocomial pathogens could be isolated from some infusion bottles as was seen with Patient 7, where in addition to the intrinsic contamination, an extrinsic contamination by multiple resistant nosocomial E. cloacae (biotype 66 / NT and ribotype E4B4) problably occurred. An extrinsic contamination was also suspected in an infusion bottle administered to
Patient 8 from which it was isolated a multiple resistant $E$. cloacae strain belonging to biotype 26 / serotype O19, and ribotype E2B2.

The high genetic heterogeneity of E. agglomerans ${ }^{4,20,21}$ makes it difficult to establish a satisfactory system for its identification. According to FARMER ${ }^{11}$, only cultures that are yellow pigmented and triple decarboxylase-negative strains are usually identified as E. agglomerans. All of our isolates that were triple decarboxylase-negative, although none was yellow pigmented, were identified as E. agglomerans. The lack of phenotypic methods to discriminate strains and to support similarities among strains of E. agglomerans is a drawback in epidemiological studies. In this study the relatedness of E. agglomerans strains isolated from solutions administered to patients, from blood cultures and from a sealed bottle of parenteral nutrition solution could be only confirmed by ribotyping. Both EcoRI and Bam HI provided a precise evidence of strains relatedness.

Ribotyping proved to be an extremely useful method to confirm the identity of our isolates as other investigators had already reported ${ }^{13,18,35,38}$. In our sample, most of E. cloacae isolates were assigned to the same ribotype (E1B1) which assesses the genetic similarity of the isolates of the main group identified as biotype 26/serotype $\mathrm{O} 3$ or 26/OR of distinct origins.

Our results suggest that E. cloacae and E. agglomerans were present in the solutions when they were delivered to the hospitals (intrinsic contamination) since at least one of the two microorganisms present in a sealed bottle was isolated from the solutions administered to 26 patients. On the other hand, recovery of the same microorganisms from blood cultures of patients using these solutions incriminates them as a vehicle of transmission of these agents during the outbreak. 


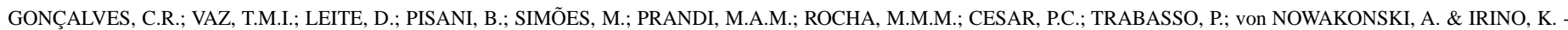
Molecular epidemiology of a nosocomial outbreak due to Enterobacter cloacae and Enterobacter agglomerans in Campinas, São Paulo, Brazil. Rev. Inst. Med. trop. S. Paulo, 42 (1): $1-7,2000$.

\section{RESUMO \\ Epidemiologia molecular de um surto de bacteriemia por Enterobacter cloacae e Enterobacter agglomerans ocorrido na região de Campinas, S. Paulo, Brasil}

Foram estudadas um total de 73 cepas (57 de E. cloacae e 16 E. agglomerans), isoladas durante um surto de bacteriemia ocorrido na região de Campinas, S. Paulo. Entre estas cepas, 61 foram isoladas de solução de nutrição parenteral, 9 de sangue, 2 de bolsa fechada de solução de nutrição parenteral e uma era de origem desconhecida. Entre as 57 cepas de E. cloacae, a maioria das cepas foram do biotipo 26/sorotipo O3 (39 cepas) e do biotipo 26/OR (13). Entre as 39 cepas de E. cloacae ribotipadas, $87,2 \%$ apresentaram o mesmo padrão de bandas com EcoRI e BamHI. Cepas de E. cloacae pertencentes ao mesmo biotipo, sorotipo e ribotipo não apresentaram diferenças significativas em relação ao padrão de sensibilidade aos agentes antimicrobianos. Todas as cepas de $E$. agglomerans, independente da origem, pertenciam ao mesmo ribotipo após a clivagem com EcoRI e BamHI. Os resultados obtidos sugerem uma contaminação intrínseca das soluções de nutrição parenteral, incriminando-as como o veículo de transmissão dos agentes etiológicos do surto.

\section{ACKNOWLEDGEMENT}

We thank Dr T.L. Pitt, Laboratory of Hospital Infection, PHLS Central Public Health Laboratory, Colindale, London, UK, for typing our 19 E. cloacae isolates and for sending us the serotype strains for $E$. cloacae.

\section{REFERENCES}

1. ARPIN, C.; ROGUES, A.M.; GACHIE, J.P. et al. - Epidemiological study of an outbreak due to multidrug-resistant Enterobacter aerogenes in a medical intensive care unit. J. clin. Microbiol., 34: 2163-2169, 1996.

2. BENNETT, S.N.; McNEIL, M.M.; BLAND, L.A. et al. - Postoperative infections traced to contamination of an intravenous anesthetic, propofol. New Engl. J. Med., 333: 147-154, 1995.

3. BRENNER, D.J.; McWHORTER, A.C.; KNUDSON, J.K. \& STEIGERWALT, A.G. Escherichia vulneris: a new species of Enterobacteriaceae associated with human wounds. J. clin. Microbiol., 15: 1133-1146, 1982.

4. BRENNER, D.J.; FANNING, G.R.; KNUTSON, J.K.L. et al. - Attempts to classify Herbicola Group-Enterobacter agglomerans strains by deoxyribonucleic acid hybridization and phenotypic tests. Int. J. system. Bact., 34: 45-55, 1984.

5. BODEY, G.P.; ELTING, L.S. \& RODRIGUES, S. - Bacteremia caused by Enterobacter: 15 years of experience in a cancer hospital. Rev. infect. Dis., 13: 550-558, 1991.

6. BURCHARD, K.W.; BARRAL, D.T.; REED, M. \& SLOTMAN, G.J. - Enterobacter bacteremia in surgical patients. Surgery, 100: 857-861, 1986.

7. BUCHHOTZ, D.H.; YOUNG, V.M.; FRIEDMAN, R.R. et al. - Bacterial proliferation in platelet products stored at room temperature: transfusion-induced Enterobacter sepsis. New Engl. J. Med., 285: 429-433, 1971.

8. CHOW, J.W.; FINE, M.J.; SHALAES, D.M. et al. - Enterobacter bacteremia: clinical features and emergence of antibiotic resistance during therapy. Ann. intern. Med., 115: 585-590, 1991.
9. EWING, W.H. - Edwards and Ewing's identification of Enterobacteriaceae. 4. ed. New York, Elsevier Science, 1986.

10. FALKINER, F. R. - Enterobacter in hospital. J. Hosp. Infect., 20: 137-140, 1992.

11. FARMER III, J.J. - Biochemical identification of new species and biogroups of Enterobacteriaceae isolated from clinical specimens. J. clin. Microbiol., 21: 46-76, 1985.

12. FARMER III, J.J. - Enterobacteriaceae: introduction and identification. In: MURRAY, P.R.; BARON, J.; TENOVER, F.C. \& YOLKEN, R.H., ed. Manual of clinical microbiology. 6.ed. Washington, American Society of Microbiology, 1995. p.438449.

13. GARAIZAR, J.; KAUFMANN, E. \& PITT, T.L. - Comparison of ribotyping with conventional methods for the type identification of Enterobacter cloacae. J. clin. Microbiol., 29: 1303-1307, 1991.

14. GALLAGHER, P.G. - Enterobacter bacteremia in pediatric patients. Rev. infect. Dis., 12: $808-812,1990$

15. GASTON, M.A.; BUCHER, C. \& PITT, T.L. - O serotyping scheme for Enterobacter cloacae. J. clin. Microbiol., 18: 1079-1083, 1983.

16. GASTON, M.A.; CREES-MORRIS, J. \& PITT, T.L. - Serotypes and biochemical profiles of British hospital strains of Enterobacter cloacae in relation to site of infection and antibiotic susceptibility. J. Hosp. Infect., 10: 17-27, 1987.

17. GHELDRE, Y.; MAES, N.; ROST, F. et al. - Molecular epidemiology of an outbreak of multidrug-resistant Enterobacter aerogenes infections and in vivo emergence of imipenem resistance. J. clin. Microbiol., 35: 152-160, 1997.

18. GRATTARD, F.; POZZETTO, B.; BERTHELOT, P. et al. - Arbitrarily primed PCR, ribotyping, and plasmid pattern analysis applied to investigation of a nosocomial outbreak due to Enterobacter cloacae in a neonatal intensive care unit. J. clin. Microbiol., 32: 596-602, 1994.

19. JALALUDDIN, S.; DEVASTER, J.M.; SCHEEN, R. et al. - Molecular epidemiological study of nosocomial Enterobacter aerogenes isolates in a Belgium hospital. J. clin. Microbiol., 36: 1846-1852, 1998.

20. LINDH, E.; KJAELDGAARD, P.; FREDERIKSEN, W. \& URSING, J. - Phenotypical properties of Enterobacter agglomerans (Pantoea agglomerans) from human, animal and plant sources. Acta path. microbiol. immunol. scand. Sect. B , 99: 347-352, 1991.

21. LIND, E \& URSING, J. - Clinical strains of Enterobacter agglomerans (synonyms: Erwinia herbicola, Erwinia milletiae) identified by DNA-DNA hybridization. Acta path. microbiol. immunol. scand. Sect. B, 94: 205-213, 1986.

22. MAKI, D.G.; RHAME, F.S.; MACKEL, D.C. \& BENNETT, J.V. - Nationwide epidemic of septicemia caused by contaminated intravenous products. I. Epidemiologic and clinical features. Amer. J. Med., 60: 471-485, 1976.

23. MAKI, D.G. \& MARTIN, W.T. - Nationwide epidemic of septicemia caused by contaminated intravenous products. IV. Growth of microbial pathogens in fluids for intravenous infusion. J. infect. Dis., 131: 267-272, 1975.

24. MAYHALL, C.G.; LAMB, V.A .; GAYLE Jr., W.E. \& HAYNES Jr., B.W. - Enterobacter cloacae septicemia in a burn center: epidemiology and control of an outbreak. J. infect. Dis., 139: 166-171, 1979.

25. MIRZA, G.E.; KARAKÜCÜK, S.; DOGANAY, M. \& CAGLAYANGIL, A. Postoperative endophthalmitis caused by Enterobacter species. J. Hosp. Infect., 26: 167-172, 1994.

26. NATIONAL COMMITTEE FOR CLINICAL LABORATORY STANDARDS Performance standards for antimicrobial susceptibilty testing. 6.ed. Approved Standard. M2-A6. Villanova, PA, 1997. 


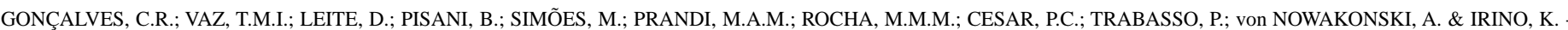
Molecular epidemiology of a nosocomial outbreak due to Enterobacter cloacae and Enterobacter agglomerans in Campinas, São Paulo, Brazil. Rev. Inst. Med. trop. S. Paulo, 42 (1): $1-7,2000$.

27. OLD, D.C. - Biotyping of Enterobacter cloacae. J. clin. Path., 35: 875-878, 1982

28. PREFEITURA MUNICIPAL DE CAMPINAS. SECRETARIA MUNICIPAL DE SAÚDE - Investigação de surto de bacteriemia/sepsis relacionado à administração de nutrição parenteral prolongada (NP) contaminada com a bactéria Enterobacter sp. Comissão de Investigação - Portaria SMS N 05/97. Abril/Maio de 1997.

29. POPOVIC, T.; BOPP, C.A. \& WACHSMUTH, K. - Epidemiologic application of a standardized ribotype scheme for Vibrio cholerae O1. J. clin. Microbiol., 31: 2474 2482, 1993.

30. SANDERS Jr., W.E. \& SANDERS, C. - Enterobacter spp: pathogens poised to flourish at the turn of the century. Clin. microbiol. Rev., 10: 220-241, 1997.

31. STRUELENS, M.J.; ROST, F.; DEPLANO, A. et al. - Pseudomonas aeruginosa and Enterobacteriaceae bacteremia after biliary endoscopy: an outbreak investigation using DNA macrorestriction analysis. Amer. J. Med., 95: 489-498, 1993.

32. THOMAS, A.; LALITHA, M.K.; JESUDASON, M.V. \& JOHN, S. - Transducer related Enterobacter cloacae sepsis in postoperative cardiothoracic patients. J. Hosp. Infect., 25: 211-214, 1993.
33. VAN NIEROP, W.J.; DUSE, A.G.; STEWART, R.G. et al. - Molecular epidemiology of an outbreak of Enterobacter cloacae in the neonatal intensive care unit of a provincial hospital in Gauteng, South Africa. J. clin. Microbiol., 36: 3085-3087, 1998.

34. WAGNER, S.J.; FRIEDMAN, L. \& DODD, R.Y. - Transfusion-associated bacterial sepsis Clin. microbiol. Rev., 7: 290-302, 1994.

35. WANG, C.C.; CHU, M.L.; HO, L.J. \& HWANG, R.C. - Analysis of plasmid pattern in paediatric intensive care unit outbreaks of nosocomial infection due to Enterobacter cloacae. J. Hosp. Infect., 19: 33-40, 1991.

36. WEISCHER, M.; KOLMOS, H.J.; KAUFMANN, M.E. \& ROSDAHL, V.T. - Biotyping, phage typing, and O-serotyping of clinical isolates of Enterobacter cloacae. Acta path. microbiol. immunol. scand. Sect. B, 101: 838-844, 1993.

37. WEISCHER, M. \& KOLMOS, H.J.- Retrospective 6-year study of enterobacter bacteraemia in a Danish university hospital. J. Hosp. Infect., 20: 15-24, 1992.

38. WEISCHER, M. \& KOLMOS, H.J. - Ribotyping of selected isolates of Enterobacter cloacae and clinical data related to biotype, phage type, O-serotype, and ribotype. Acta path. microbiol. immunol. scand. Sect. B, 101: 879-886, 1993.

Received: 03 September 1999

Accepted: 11 January 2000 


\section{SUMMARY OF THESIS*}

CAVALHEIRO, Norma de Paula - Análise dos sorotipos do VHC identificados em pacientes da cidade de São Paulo, através de método imunoenzimático. São Paulo, 1999. (Dissertação de Mestrado - Faculdade de Medicina da Universidade de São Paulo).

\section{ANALYSIS OF SEROTYPES OF HCV IN PATIENTS FROM THE CITY OF SÃO PAULO, BY MEANS OF A ENZYME-IMMUNOASSAY METHOD}

With the objective of analyzing the prevalence of the different types of Hepatitis C Virus (HCV) in a population of chronic carriers of HCV, through a serologic method (MUREX HCV Serotyping Assay), 219 patients were studied who showed a positive polymerase chain reaction. This sera were submitted to immunoenzymatic tests for the detection of antibodies in relation to HCV types $1,2,3,4,5$ and 6 . The samples were diluted and incubated in the presence of heterologous competing peptides, with microwells coated with serotype-specific antigens of HCV. Of the 219 patients, it was possible to detect the HCV serotype in 166, revealing a sensitivity of $75.8 \%$. The results showed a predominance of type $1(70.0 \%)$ in our medium, followed by type $3(22.3 \%)$ and type 2 $(4.2 \%)$. Serotypes 4 and 5 were present in $1.8 \%$ of the patients, but always associated with serotype 1 . These samples, in spite of fulfilling the prerequisites of validity for testing, showed a very high optical density reading for all types of viruses tested, including positive and negative controls. The possibility of cross reactions in these cases should be considered. Confirmation by genotyping and a more detailed investigation on the origin and mode of acquisition of the HCV of these patients should be researched. Type 6 was not confirmed in any of the samples tested and probably was not present in this particular collection. The epidemiological parameters evaluated were: age, sex and means of transmission. Of the 166 patients diagnosed with the HCV, 108 (65.1\%) were men and $58(34.9 \%)$ were women. The age of the patients varied from 12 to 73 years, the average being 41.1 years. The means of transmission mentioned were blood transfusion in $52(31.3 \%)$ cases, intravenous drug use in $18(10.8 \%)$ cases, by tattoos in $8(4.8 \%)$ cases, $6(3.6 \%)$ cases were sexually transmitted, $3(1.8 \%)$ were by accident with a needle, $2(1.2 \%)$ through work in the health field, one $(0.6 \%)$ through acupuncture and one by being hemophiliac. Sixty one (36.7\%) patients were not able to offer any risk factor which justified the acquisition of the HCV infection. No significant difference was verified among the different types of HCV found and the different epidemiological parameters studied. The predominance of types 1, 3 and 2 is compatible with other genotyping studies which involved Brazilian samples, particularly in the city of São Paulo. The samples which showed high or low dense optical reading for all the wells of the same samples tested even the positive or negative controls, suggested confirmation by sequencing or genotyping. The practicality obtained by the HCV serotyping test, in spite of the fact that it does not identify the sub type, can be useful in clinical practice and helpful in the prognostication of the disease, not needing the technology demanded by the tests which involve molecular biology. 